\title{
New Opportunities and Untapped Scientific Potential in the Abyssal Ocean
}

\author{
Jeffrey J. Marlow ${ }^{1 *}$, Rika E. Anderson ${ }^{2}$, Anna-Louise Reysenbach ${ }^{3}$, Jeffrey S. Seewald ${ }^{4}$, \\ Timothy M. Shank ${ }^{5}$, Andreas P. Teske ${ }^{6}$, V. Dorsey Wanless ${ }^{7}$ and S. Adam Soule ${ }^{8 *}$ \\ ${ }^{1}$ Department of Biology, Boston University, Boston, MA, United States, ${ }^{2}$ Biology Department, Carleton College, Northfield, \\ MN, United States, ${ }^{3}$ Biology Department, Portland State University, Portland, OR, United States, ${ }^{4}$ Department of Marine \\ Chemistry and Geochemistry, Woods Hole Oceanographic Institution, Woods Hole, MA, United States, ${ }^{5}$ Biology \\ Department, Woods Hole Oceanographic Institution, Woods Hole, MA, United States, ${ }^{6}$ Department of Earth, Marine \\ and Environmental Sciences, University of North Carolina-Chapel Hill, Chapel Hill, NC, United States, ${ }^{7}$ Department \\ of Geosciences, Boise State University, Boise, ID, United States, ${ }^{8}$ Graduate School of Oceanography, University of Rhode \\ Island, Narragansett, RI, United States
}

OPEN ACCESS

Edited by:

Elva G. Escobar-Briones, National Autonomous University

of Mexico, Mexico

Reviewed by:

Nadine Le Bris,

Sorbonne Université, France

Christian Tamburini,

UMR7294 Institut Méditerranéen d'océanographie (MIO), France

*Correspondence: Jeffrey J. Marlow jjmarlow@bu.edu

S. Adam Soule adamsoule@uri.edu

Specialty section:

This article was submitted to Deep-Sea Environments and Ecology, a section of the journal Frontiers in Marine Science

Received: 20 October 2021 Accepted: 28 December 2021 Published: 03 February 2022

Citation:

Marlow JJ, Anderson RE, Reysenbach A-L, Seewald JS, Shank TM, Teske AP, Wanless VD and Soule SA (2022) New Opportunities and Untapped Scientific Potential

in the Abyssal Ocean

Front. Mar. Sci. 8:798943. doi: 10.3389/fmars.2021.798943
The abyssal ocean covers more than half of the Earth's surface, yet remains understudied and underappreciated. In this Perspectives article, we mark the occasion of the Deep Submergence Vehicle Alvin's increased depth range (from 4500 to $6500 \mathrm{~m}$ ) to highlight the scientific potential of the abyssal seafloor. From a geologic perspective, ultra-slow spreading mid-ocean ridges, Petit Spot volcanism, transform faults, and subduction zones put the full life cycle of oceanic crust on display in the abyss, revealing constructive and destructive forces over wide ranges in time and space. Geochemically, the abyssal pressure regime influences the solubility of constituents such as silica and carbonate, and extremely high-temperature fluid-rock reactions in the shallow subsurface lead to distinctive and potentially unique geochemical profiles. Microbial residents range from low-abundance, low-energy communities on the abyssal plains to fast growing thermophiles at hydrothermal vents. Given its spatial extent and position as an intermediate zone between coastal and deep hadal settings, the abyss represents a lynchpin in global-scale processes such as nutrient and energy flux, population structure, and biogeographic diversity. Taken together, the abyssal ocean contributes critical ecosystem services while facing acute and diffuse anthropogenic threats from deep-sea mining, pollution, and climate change.

Keywords: abyssal ocean, geochemistry, microbiology, geology, ecology

\section{INTRODUCTION}

The abyssal ocean, which includes the water column and seafloor between 3000 and $6000 \mathrm{~m}$ depth (Vinogradova, 1997), constitutes 54\% of Earth's surface (Gage and Tyler, 1991). It is a geologically, geochemically, and biologically diverse realm comprising broad sedimented plains, steep trenches, fractured crustal foundations, towering seamounts, sweeping currents, and an extensive water column. The uniqueness of the abyssal ocean is shaped both by features found dominantly or exclusively at these depths, as well as features typically encountered in other zones but overprinted by 30-60 MPa of hydrostatic pressure. Abyssal environments are vast and varied, but have been 
largely out of reach for scientific investigation due to their distance from shore and depth beneath the ocean's surface. However, the abyssal ocean likely holds critical clues to longstanding scientific questions pertaining to the flow of mantlederived energy, the mobilization of chemicals into ocean waters, and the origin, evolution, and distribution of life. Abyssal environments are largely unexplored and poorly understood, but given its volumetric importance and unique geological, geochemical, and biological attributes, we feel that increased scientific attention to the abyssal ocean has the potential to alter our understanding of the global ocean processes in fundamental ways. Based on a recent series of collaborative workshops among the research community, ${ }^{1}$ we highlight some of the key scientific priorities at abyssal depths. This part of the ocean represents a lynchpin in global-scale processes such as nutrient and energy flux, population structure, and biogeographic diversity. It contributes critical ecosystem services while facing acute and diffuse anthropogenic threats from deep-sea mining, pollution, and climate change.

Integrated exploratory opportunities to rigorously investigate the abyss require access by remotely operated vehicles (ROVs) and autonomous underwater vehicles (AUVs), as well as stationary tools such as landers, coring instruments, and water samplers. In 2022, the United States scientific community will have reliable human-occupied access to the abyss for the first time (joining a short list of other nations and private organizations with such capabilities; see Supplementary Table 1) as the Deep Submergence Vehicle (DSV) Alvin returns to service after an overhaul that increased its depth range from 4500 to $6500 \mathrm{~m}$. However, access alone is not enough to address exploratory and scientific gaps: despite ROV Jason's $6500 \mathrm{~m}$ rating, for example, just $6.5 \%$ of its dives have been conducted below $4500 \mathrm{~m}$. Rather, a focused and sustained effort from both the research community and sponsoring organizations is needed to realize the substantial scientific and societal gains to be derived from abyssal work. We take Alvin's debut in this domain as an opportunity to illuminate the discovery potential of the abyss, and to call attention to the broader relevance of this critical marine zone.

\section{THE FULL LIFE CYCLE OF OCEANIC CRUST IS EXPOSED ACROSS ABYSSAL DEPTHS}

Magmatic and tectonic processes provide a fundamental control on the shape of ocean basins and, through plate cooling, subsidence, and plate boundary distribution, define the extent of abyssal depths. At all depths, these same processes control heat distribution and mass transfer through the seabed, influence planetary-scale chemical cycles, and structure the habitat for benthic organisms. However, the abyssal ocean is host to a number of geological features that are unique to this depth range and that drive poorly understood processes (Figure 1).

\footnotetext{
${ }^{1}$ https://ndsf.whoi.edu/alvin/workshop-alvin-in-the-abyss/
}

Petit Spots, for example, are a unique form of volcanism that occurs where tectonic plates bow upward at the outer rise of subduction zones, typically at depths $>5000$ m (Hirano et al., 2006, 2019; Hirano, 2011; Machida et al., 2017). These isolated magmatic features sample portions of Earth's upper mantle that are otherwise inaccessible, offering a unique window into mantle compositions, subsurface heat flow, and elemental cycling. Petit Spot volcanoes occur far from the relatively well-understood magmatic heat sources at mid-ocean ridges and mantle plumes, and their impact on biological processes and crustal evolution remain the subject of speculation. Although dozens of Petit Spots have recently been identified (Hirano et al., 2013, 2019), only a few targeted submersible dives have been conducted, leaving substantial opportunities for campaigns to characterize Petit Spots across a range of settings.

As a result of extensive fracturing at transform faults, subduction zones, and ultraslow spreading mid-ocean ridges (Auzende et al., 1989; Francheteau et al., 1990; Fryer, 2002), abyssal depths often provide an opportunity to directly observe and sample the roots of mid-ocean ridge magmatic and hydrothermal systems. These features can inform models of heat and chemical flux, which strongly influence ocean chemistry. For example, samples of exposed upper mantle from the subducting plate at the Puerto Rico trench have revealed the timing and extent of hydration (i.e., serpentinization) of crust generated at the Mid-Atlantic Ridge (Klein et al., 2017). Such findings help constrain the degree of chemical exchange between the lithosphere and hydrosphere, the nature of subseafloor biological energy sources, the extent of magmatic processes at subduction zones (Klein et al., 2017), and the fluxes of global-scale water cycling (Rüpke et al., 2004; van Keken et al., 2011).

Tectonically inactive, abyssal plains are generally considered to be heavily sedimented. However, a recent examination of the northern Mid-Atlantic Ridge seafloor revealed an unexpectedly high proportion of rock cover (Riehl et al., 2020), contributing a broader range of substrates that likely drives biodiversity patterns (Levin et al., 2001). In addition, the relatively flat abyssal plains are punctuated by thousands of seamounts: of the $>11,000$ seamounts identified via satellite altimetry in the global ocean (Wessel et al., 2010), more than 8,000 are rooted at abyssal depths. At shallower depths, seamounts are recognized as biological hotspots, but the degree to which these factors translate to deeper seamounts remains unclear.

The long-term environmental stability of abyssal plains and seamounts contributes to the formation of ferro-manganese crusts and polymetallic nodules. These slowly depositing crusts precipitate from bottom waters, possibly mediated by microbial Mn oxidation (Blöthe et al., 2015; Shulse et al., 2017), and provide a long-term record of redox chemistry, ocean current dynamics, continental erosion (Koschinsky and Hein, 2017) and magnetic field patterns (Yi et al., 2020). In addition, they concentrate metals such as cobalt, copper, and nickel and have long been viewed as a potential source of raw materials for industrial use (Lusty and Murton, 2018; Miller et al., 2018). Studying the formation processes of abyssal ferro-manganese crusts and polymetallic nodules-as well as the associated ecology of the deposits-is 

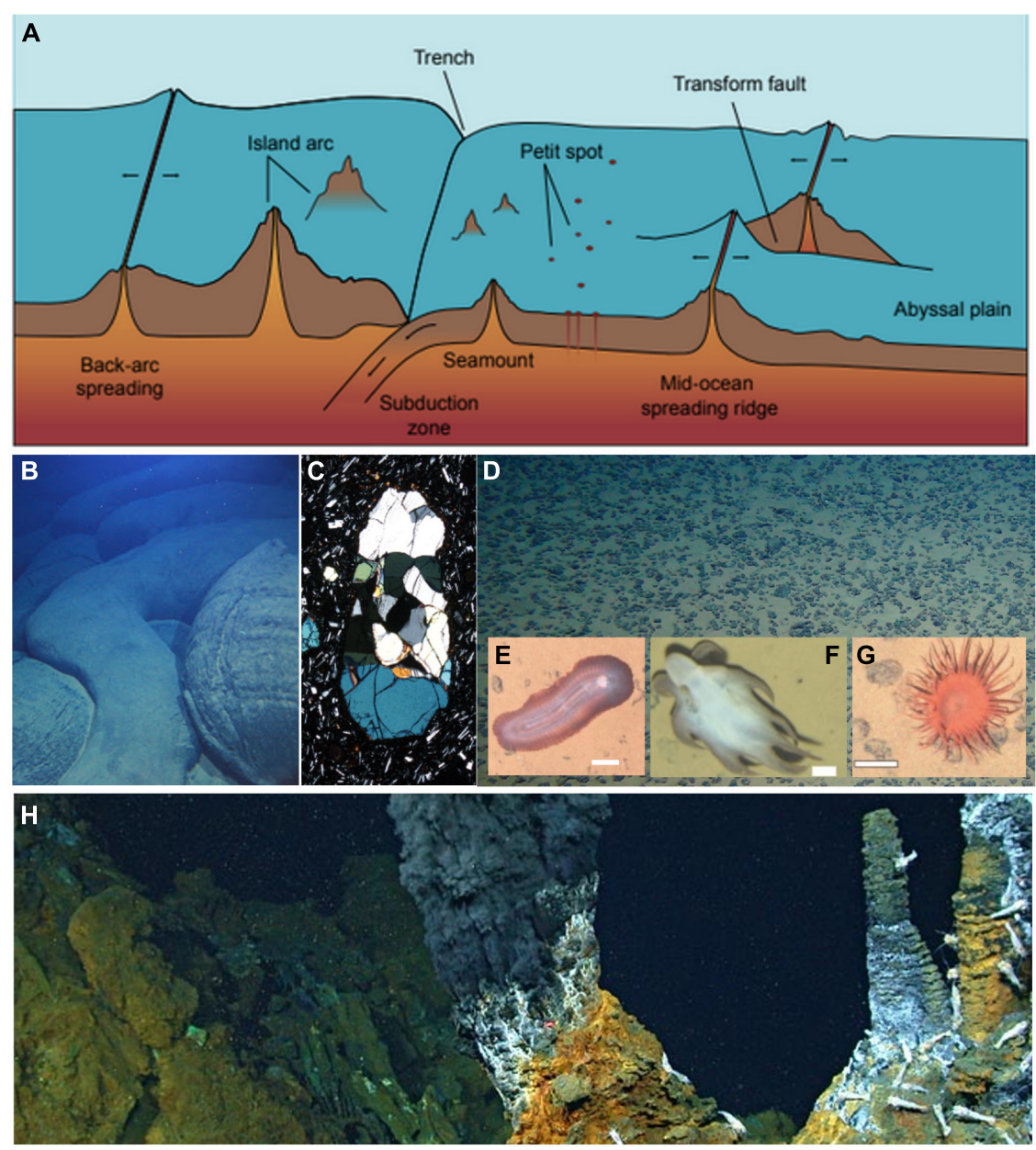

FIGURE 1 | Abyssal seafloor features in the context of open ocean environments. (A) A schematic outline of the diverse habitats and features on the abyssal seafloor, some of which extend above and/or below the abyssal zone. (B) Pillow basalt at a Petit Spot seafloor volcano, providing a window into the earth's upper mantle through (C) peridotite xenoliths (image $2 \mathrm{~mm}$ across). (D) Abyssal seafloor nodules at the Clarion-Clipperton zone; insets show (E) Benthodytes, (F) Grimpoteuthis, and (G) Actiniaria; all scale bars $5 \mathrm{~cm}$. (H) Hydrothermal chimneys with vent shrimp at the Piccard hydrothermal field. [Image credits: (B) Tohoku University; (C) Morishita et al. (2020); (D) GEOMAR; (E) Simon-Lledó et al. (2019); (F) Simon-Lledó et al. (2020); (G) Simon-Lledó et al. (2019); (H) Chris German, WHOI/NASA].

particularly urgent given the widespread potential impacts of mining.

\section{DEEPER AND HOTTER: DISTINCT GEOCHEMICAL ENVIRONMENTS AT ABYSSAL DEPTHS}

Subseafloor fluid flow plays a direct and highly variable role in regulating physical and chemical conditions in marine sediment and crustal environments. Conductive heating and chemical modification of seawater-derived fluids result in extensive heat and mass exchange between the water column and the lithosphere. The resulting environments include high temperature hydrothermal vents at slow and ultra-slow spreading centers such as the Piccard, Aurora, and Ashadze 1 vent fields (Charlou et al., 2010; Connelly et al., 2012; McDermott et al., 2018, 2020), and low temperature diffuse flow at the Loihi
Seamount (Edwards et al., 2011). However, Petit Spots, ultraslow spreading centers, subduction zones, and seamounts located at abyssal depths are all characterized by thermal gradients, seafloor topography, and high permeability, creating conditions for subseafloor fluid circulation. Indeed, hydrothermal activity has been inferred from chemical anomalies in the overlying water column at several sites (German and Seyfried, 2014), offering hints of geochemically distinct sites and the global impacts of vent systems.

The increased hydrostatic pressure in the abyss directly impacts quartz solubility (Von Damm et al., 1991), resulting in enhanced aqueous silica concentrations that influence the stability of aluminosilicate minerals and regulate the composition of hydrothermal fluids. Moreover, maximum temperatures of hydrothermal fluids are determined by the temperature and pressure dependence of fluid density (Bischoff and Rosenbauer, 1985). Accordingly, at the Piccard vent field located in $5000 \mathrm{~m}$ of water at the Mid-Cayman Rise spreading center, 
temperatures estimated for subsurface reaction zones exceed $500^{\circ} \mathrm{C}$ (McDermott et al., 2018; Scheuermann et al., 2018, 2020), which is substantially higher than shallower submarine vents. Higher subsurface temperatures significantly influence vent fluid composition at Piccard. In particular, concentrations of dissolved $\mathrm{H}_{2}$-an important electron donor for many chemosynthetic microorganisms-reached the highest levels documented to date (McDermott et al., 2018).

In abyssal depths, extensive faulting that is commonly observed at transform faults, subduction zones, and mid-ocean ridges may facilitate the interaction of seawater-derived fluids with upper mantle ultramafic rocks to a heightened degree. Aqueous alteration of ultramafic rocks at temperatures below $\sim 400^{\circ} \mathrm{C}$ results in serpentinization reactions (Klein et al., 2013), a process that alters the rheology and permeability of the lithosphere. Oxidation of ferrous iron during serpentinization may result in the formation of $\mathrm{H}_{2}$ and highly reducing fluids that support microbial communities (Takai et al., 2004; Flores et al., 2011; Schrenk et al., 2013; Reveillaud et al., 2016). Elevated $\mathrm{H}_{2}$ concentrations also create conditions conducive to the abiotic synthesis of aqueous organic compounds, including postulated prebiotic compounds, leading many to suggest that serpentinizing systems may have contributed to the origin of life (Martin et al., 2008; Sleep et al., 2011). The existence of unexplored regions of the abyssal ocean where ultramafic rocks may be exposed at the seafloor, along with other active environments that are conducive to extensive fluid flow, suggests that the abyssal ocean may have much to teach us about fluid-rock interaction and elemental cycling on a global scale.

\section{MICROBIAL COMMUNITIES IN THE ABYSS EXPERIENCE FEAST, FAMINE, AND EVERYTHING IN BETWEEN}

The geological and geochemical systems in the abyss create a wide range of distinct habitats for microbial communities. In abyssal plain sediments, microbial communities are particularly constrained by the availability of electron donors and carbon sources. Only a small, highly recalcitrant fraction of organic matter reaches the deep seafloor to sustain heterotrophic, sediment-hosted microbes (Wakeham et al., 1997). Where surface waters exhibit low levels of primary production, such as in the ultraoligotrophic subtropical gyres, extremely organic-lean and fully oxic sediments of the deep abyssal plains show the lowest microbial cell densities of all marine sediments (D'Hondt et al., 2009, 2015). Low rates of microbial respiration in these sediments limit energy availability, essentially locking subsurface microbes into extended metabolic stasis over millions of years (Røy et al., 2012; Bradley et al., 2020). Abyssal plains thus represent a promising site at which to study the energy limits of life and evolutionary processes in low-energy habitats. Given these very low growth rates, the recovery of abyssal plain microbial communities in the face of environmental disturbances would be extremely slow. Autotrophy, the metabolic process whereby inorganic rather than organic carbon is used to build biomass, is limited, but has been detected in abyssal habitats including subseafloor crustal fluids (Meyer et al., 2016) and manganese nodule fields (Sweetman et al., 2019), though the distributions of electron donors and energy sources have yet to be well quantified.

While organic-lean conditions are typical of abyssal sediments, organic falls in the form of dead jellyfish (Billett et al., 2006), whales (Smith et al., 2015), and other animals can deliver substantial localized sources of carbon and nutrients to the seafloor. These transient habitats may persist for several decades or longer (Smith and Baco, 2003; Smith et al., 2015), promoting blooms of heterotrophic, sulfate-reducing, and sulfide-oxidizing microbes (Goffredi and Orphan, 2010). Organic falls may also serve as stepping stones between more permanent chemosynthetic habitats (Smith et al., 2015), signifying an important biogeographical structuring regime across the abyssal seafloor for microbes and animals alike.

In contrast to the abyssal plains, deep-sea trench habitats at active continental margins are characterized by the focused deposition of continental sedimentary input and marine snow from areas of high primary productivity. As a result, trench sediments can be fully reduced, organic-rich, and abundantly populated by microbes (D'Hondt et al., 2004; Inagaki et al., 2006). The diverse habitats of deep-sea trenches include lowtemperature serpentinite-hosted seeps along forearc trench walls (Ohara et al., 2012), as well as methane seeps hosting anaerobic methanotrophic microbial consortia (Felden et al., 2014) and invertebrate fauna with sulfide- and methaneoxidizing chemosynthetic symbionts (Fujikura et al., 1999). The range of depths at which methane seeps have been discovered, particularly in abyssal zones (Juniper and Sibuet, 1987; BellanSantini, 1990; Suess et al., 1998), offers an opportunity to evaluate the effects of carbonate saturation state on carbonatehosted microbial activity and the broader role of seeps in global carbon cycling.

Initial observations indicate that microbial communities at abyssal hydrothermal vents may be distinct from those in non-abyssal zones. The deepest currently known hydrothermal site, the basalt-hosted Piccard vents (Kinsey and German, 2013), harbors sulfide- and hydrogen-oxidizing, sulfate-reducing, and methanogenic microbial communities that are distinct from those of shallower vent sites (Reveillaud et al., 2016). Surprisingly, their closest counterparts are not the microbial communities inhabiting other basalt-hosted vents, but rather those in the nearby serpentinization-influenced Von Damm system (Reveillaud et al., 2016). At an entirely different locationthe cool, Fe-rich hydrothermal site of Ula Nui at the base of Loihi seamount (Hawai'i)-the oxidation of ferrous iron with nitrate provides energy for massive chemosynthetic microbial mats that have no counterpart at hot vent sites (Edwards et al., 2011; Sylvan et al., 2017). These examples illustrate that abyssal vent studies are certain to expand our understanding of hydrothermal microbial diversity while posing new questions about microbial biogeography.

While the primary controls of carbon and energy supply are clearly important in structuring community composition, 
the physiological characteristics and capabilities of abyssal Bacteria and Archaea reveal site-specific optimizations (LeónZayas et al., 2015). One pervasive characteristic that enables microbial survival in abyssal waters and sediments is the fine-tuning of cellular processes, enzymatic activities, and biological structures such as membranes to high hydrostatic pressure regimes (Bartlett, 2002). Maintaining in situ pressures throughout the sampling-to-experimentation process is essential for quantitative assessments, as measurements made using decompressed samples under atmospheric pressure underestimate in situ metabolic activity (Tamburini et al., 2013). The expanded depth capabilities of DSV Alvin present a unique opportunity to test new sampling technology and better understand the physiology, ecology, and evolution of abyssal microbial communities, and to provide insights into how they shape and are shaped by global biogeochemical processes.

\section{THE ABYSSAL SEAFLOOR PROVIDES A VAST NATURAL LABORATORY FOR EVOLUTIONARY AND BIOGEOGRAPHICAL STUDIES OF MARINE ANIMALS}

Variations in geologic context, geochemical compositions, and food and energy availability create genetically isolated biological habitats in the abyss that vary in both time and space. This heterogeneity controls fundamental parameters that structure ecosystems and govern evolutionary processes, including trophic dynamics, colonization, growth rates, reproduction, speciation, endemism, and biogeographic diversity (Brandt et al., 2007; Mullineaux et al., 2010; Zeppilli et al., 2016; Snelgrove et al., 2018).

One area that has received increased attention is the ClarionClipperton Zone (CCZ), a six million square kilometer region of abyssal $(>3000 \mathrm{~m}$ ) seafloor in the Pacific (Figure 1). The region harbors some of the world's most abundant deposits of polymetallic nodules (enriched in copper, nickel, cobalt and other minerals), seamounts, and other topographical features (Wedding et al., 2013). At just four sites within a $\sim 900 \mathrm{~km}^{2}$ area of the CCZ, megafaunal diversity exceeded that of other abyssal locations and exhibited a strong dependence on habitat heterogeneity. Half of the observed animals were exclusively associated with nodules, and more than half of the collected metazoan species were new to science (Amon et al., 2016). More broadly, hard substrates play a role in selecting for novel biodiversity on the seafloor and represent a promising area for biodiversity discovery. Seamounts, for example, are often considered island habitats that can promote endemism (Shank, 2010), but very little is known about the biodiversity of their flanks. The recently revealed prevalence of rocky seafloor in the abyss dramatically expands the habitability and speciation potential for sessile organismssuch as sponges, corals, and foraminifera-across ocean basins (David et al., 2017; Riehl et al., 2020). From recently formed oceanic crust at spreading centers to $100+$ million yearold crust at subduction zones, the abyssal seafloor provides unique opportunities for comparing colonization, biodiversity patterns, and evolution of fauna across enormous ranges in time and space.

The insights derived from studying fundamental biodiversity patterns and processes in the bathyal regions (Brandt et al., 2007; Rex and Etter, 2010) provide a strong comparative framework for developing testable hypotheses to isolate causative variables that link evolutionary adaptations to ecological context in the abyssal zone. Efforts to date have focused largely on kinetic and chemical energy delivery from overlying waters (Woolley et al., 2016), but the distinct character of seafloor substrates and the trophic dynamics seeded by seafloor communities warrant closer attention. For example, high-relief features such as seamounts and trench walls enable studies of ecological gradations between bathyal and abyssal zones. Studies across these depth ranges at select seamounts show no clear pattern of megafaunal diversity or biomass with depth (McClain et al., 2010; McClain and Lundsten, 2015), but did reveal substantial changes in the community composition: up to $50 \%$ turnover across a 1500-m depth interval (McClain and Barry, 2010). By comparing these depth-based biodiversity associations with those established in shallower waters (Nomaki et al., 2008; Tecchio et al., 2013), an exciting opportunity exists to integrate the abyssal seafloor and the unique environmental parameters it encompasses-vast areas and elevated pressures, among them-into generalizable models of animal biodiversity in the deep sea.

\section{ABYSSAL SEAFLOOR "OUT OF SIGHT, OUT OF MIND" NO MORE}

A renewed focus on abyssal depths provides an opportunity to reconsider and communicate the ways in which deep-sea science directly impacts society. Most of the abyssal seafloor is in areas beyond national jurisdiction and thus comprises the "common heritage of humankind." In this context, it is critical to engage a diverse global community of scientists and advocates to understand, manage, and accurately value the deep seafloor.

Abyssal plains underlie the majority of the ocean; the native microbial communities in abyssal sediments mobilize and regenerate nutrients, and are key players in a food web that includes commercial fisheries (Thurber et al., 2014). The vast and poorly explored genetic diversity of seafloor microorganisms is of interest to bioprospectors in search of compelling secondary metabolites, as well as scientists seeking clues to the origin of life and its possibility beyond Earth (Orcutt et al., 2020).

The abyssal seafloor is also a site of substantial carbon sequestration that modulates atmospheric reservoirs and constitutes an important ecosystem service. The "biological pump" of sinking organic matter moves carbon out of the atmosphere and into abyssal sediments, supporting microbial communities that in turn underlie intricate food webs (Herndl and Reinthaler, 2013). The inter-related "carbonate pump" specifies the downward export of inorganic carbon $\left(\mathrm{CaCO}_{3}\right)$, 
primarily in the form of planktonic tests. As these biologically produced particles sink below the carbonate compensation depth-typically between 4200 and $5000 \mathrm{~m}$ in the Atlantic (somewhat shallower in the more DIC-enriched Pacific)-they dissolve, leading to a seafloor carbon budget distinct from that of shallower sediments. Any modification in these parameters from continued anthropogenic activity could have dramatic carbon cycle consequences. For example, climatic influence on the quantity and episodic nature of carbon export remains to be clarified (Smith et al., 2018).

Given the scale of anthropogenic pollution and mixing associated with oceanic circulation, abyssal depths are a repository for a wide range of pollutants such as industrial organic molecules, toxic waste (Thiel, 2003), and plastics (Van Cauwenberghe et al., 2013), which may arrive via adsorption onto sinking particles, transport from surface runoff, and/or deliberate dumping (Dachs et al., 2002). Benthic (micro)biota decompose a subset of these pollutants, minimizing their harmful potential, while others can bioaccumulate up the food chain (Jamieson et al., 2017) or persist over ecologically relevant timescales (Krause et al., 2020). Understanding the ways in which pollutants are processed in bathyal zones, particularly in depot centers such as island arc trenches, will expose important controls on the (bio)chemical hazards at abyssal depths and deeper habitats.

The pending deep-sea mining industry is poised to impact abyssal depths, which host hydrothermal vent fields and seamounts, as well as the majority of ferromanganese nodule fields. Nodules accumulate manganese over millions of years (Boltenkov, 2012) and must therefore be considered nonrenewable resources. With such slow rates of deposition and mineralogical accretion, disturbances from seabed mixing, nodule removal, and sediment plume production are likely to be comprehensive and long-lasting (Vanreusel et al., 2016; Jones et al., 2017; Spearman et al., 2020). The aspiration of "no net loss of biodiversity" is unrealistic (Niner et al., 2018), and monitoring the short, medium, and long-term effects on a range of ecosystem services is a key priority for abyssal science. More broadly, the patchiness of diversity and slow rates of biological growth and recovery of disturbed sediments (Vonnahme et al., 2020) makes abyssal environments particularly vulnerable to multiple simultaneous stressors.

The deep sea-and the abyssal zone in particular, which includes neither continent-adjacent subduction zones nor the exotic deep trenches-rarely features in most people's conception of the ocean. And yet, because of its vastness alone, the abyss exerts a strong impact over global biogeochemical cycles, the ocean's response to climate change, and the conservation of biodiversity. Given the acute and distributed threats facing the abyssal seafloor, combined with our relative lack of knowledge regarding foundational ecosystem services (Le et al., 2017; Orcutt et al., 2020), research across abyssal habitats needs to be rapidly expanded and prioritized. It is also imperative that the scientific and policy communities develop research, conservation, and management plans that incorporate the needs and priorities of all nations. Achieving this aim will require sustained effort at every level of engagement with abyssal depths, from planning research efforts, to collecting samples, performing analyses, disseminating results, and translating data into policy.

\section{AN INTEGRATED VISION FOR THE SCIENTIFIC EXPLORATION OF ABYSSAL DEPTHS}

The abyss has largely escaped scientists' attention and interrogation. Nonetheless, the potential for both fundamental discovery and transferable knowledge derived from the abyssal ocean is enormous. To access these benefits, several technical and structural obstacles must be overcome, and all deep submergence technologies must be leveraged. High-pressure samplers that preserve native pressure conditions (e.g., McNichol et al., 2016; Cario et al., 2019; Garel et al., 2019; Peoples et al., 2019) are required to better understand how microbes and other life forms have adapted to high pressure, and how pressure affects physiology, community composition, and ecology. With extensive sample transit times through the water column, the risk of signal degradation and contamination increases, making in situ sensing (Chua et al., 2016) and sample processing and preservation (Fortunato et al., 2021) a high technical priority. The Alvin submersible is well positioned to deploy, manipulate, and collect such instruments, while also offering users the benefit of minimal "psychological distance" and the interpretive immediacy it entails (Trope and Liberman, 2010).

Deep submergence vehicles represent essential tools to inspire the public and advance deep-sea research around the world. While these assets have been in use for decades, many have been decommissioned; to the best of our knowledge, only five countries possess human-occupied submersibles capable of reaching abyssal depths (Supplementary Table 1). Beyond DSVs, a wide range of other exploration, observation, and sampling modalities provide complementary capabilities and expanded access to abyssal depths over both time and space. ROVs offer extended bottom time, a higher risk tolerance than DSVs, and cable-mediated transmission of live data streams, including video. Autonomous underwater vehicles, perhaps in concert with machine learning to facilitate fauna and feature identification (Langenkämper et al., 2017; Boulais et al., 2020), can obtain baseline information on patterns of biodiversity and geological features. Seabed landers and rovers have proven especially promising for in situ respiration measurements (Sweetman et al., 2019; Smith et al., 2021), though targeting specific features for analysis can be challenging. Leveraging the comparative power and multi-decade data sets of abyssal observatories focused on surface-to-seafloor processes (Soltwedel et al., 2016; Smith et al., 2020; Hartman et al., 2021), additional observatories across a broader set of abyssal environments would further refine our understanding of detrital fluxes and seafloor biogeochemical activity. Such cable-powered observatories can also serve as bases for seafloor crawlers controlled via internet link (Purser et al., 2013), which can regularly survey a localized area $\left(15,000 \mathrm{~m}^{2}\right)$ with nuanced bathymetric features for parameters such as carbon input from overlying waters (Thomsen et al., 2017) and megafaunal behavior (Chatzievangelou et al., 2016). 
Perhaps most fundamentally, the pronounced focus on hypothesis-driven deep-sea research generates a chicken-andegg conundrum: securing resources to investigate unseen sites is difficult without substantial preliminary knowledge, but developing well-supported predictions without reliable access is equally challenging. To overcome our limited knowledge of this vast and critically important ocean zone, a renewed focus on targeted exploration and discovery is urgently needed to rapidly advance our scientific understanding of the oceans before the abyss is forever changed by anthropogenic forces. We recommend that trans-disciplinary baseline observations and samples for community use be prioritized to enable distributed and community-driven exploration of abyssal environments.

The occasion of Alvin's re-introduction to the community of deep-sea scientists also offers a chance to re-evaluate who exactly that community includes and who it serves. Geosciences are among the least racially diverse scientific disciplines in the United States (Wilson, 2019), a situation that has changed little over the last four decades (Bernard and Cooperdock, 2018). Acknowledging this problem of inequity and taking individual and collective action to rectify it should be a formalized component of any research program (Dutt, 2020; Pickrell, 2020). For example, recruitment efforts should be expanded beyond default networks, and field work and research cruise culture must be consistently welcoming and inclusive. More broadly, access to deep-sea environments is unevenly distributed, meaning that many countries with clear and direct interests in marine science lack the ability to pursue actionable knowledge. Involving scientists from traditionally marginalized countries in a process of "co-development, co-production, and co-dissemination" throughout a research project and beyond is critical if we hope to make the most of limited access to the deep sea (Woodall et al., 2021). All of these efforts will not only push back against long standing injustices, but will also bolster the quality and relevance of the research endeavor (Freeman and Huang, 2014; Page, 2019), as the full range of creativity, perspectives, and expertise is deployed in the quest to address urgent questions about our planet, questions whose answers will affect us all.

\section{REFERENCES}

Amon, D. J., Ziegler, A. F., Dahlgren, T. G., Glover, A. G., Goineau, A., Gooday, A. J., et al. (2016). Insights into the abundance and diversity of abyssal megafauna in a polymetallic-nodule region in the eastern Clarion-Clipperton Zone. Sci. Rep. 6:30492. doi: 10.1038/srep30492

Auzende, J., Bideau, D., Bonatti, E., Cannat, M., Honnorez, J., Lagabrielle, Y., et al. (1989). Direct observation of a section through slow-spreading oceanic crust. Nature 337, 726-729.

Bartlett, D. (2002). Pressure effects on in vivo microbial processes. Biochim. Biophys. Acta BBA Protein Struct. Mol. Enzymol. 1595, 367-381. doi: 10.1016/ s0167-4838(01)00357-0

Bellan-Santini, D. (1990). Mediterranean deep-sea amphipods: composition, structure and affinities of the fauna. Prog. Oceanogr. 24, 275-287.

Bernard, R. E., and Cooperdock, E. H. (2018). No progress on diversity in 40 years. Nat. Geosci. 11, 292-295. doi: 10.1038/s41561-0180116-6

\section{DATA AVAILABILITY STATEMENT}

The original contributions presented in this work are included in the article/Supplementary Material. Further inquiries can be directed to the corresponding authors.

\section{AUTHOR CONTRIBUTIONS}

A-LR and SAS convened the workshops on which this manuscript was based. JM, A-LR, and SAS organized and edited the manuscript. All authors served as workshop leaders, organized and synthesized results, and contributed portions of the manuscript.

\section{FUNDING}

We would like to thank the National Science Foundation for their support through grants NSF 2009117 and 2129431 to SAS.

\section{ACKNOWLEDGMENTS}

The work presented here resulted from in-depth discussions during four collaborative workshops convened to identify key research priorities in the abyssal ocean. We thank the UniversityNational Oceanographic Laboratory System's Deep Submergence Science Committee and WHOI's National Deep Submergence Facility. We would like to thank Emily St. John for assistance in preparing Figure 1, and Andy Burnett and Knowinnovation for facilitating the collaborative workshops. We appreciate the time and expertise volunteered by dozens of scientists from around the world who participated in the workshops.

\section{SUPPLEMENTARY MATERIAL}

The Supplementary Material for this article can be found online at: https://www.frontiersin.org/articles/10.3389/fmars. 2021.798943/full\#supplementary-material

Billett, D., Bett, B., Jacobs, C., Rouse, I., and Wigham, B. (2006). Mass deposition of jellyfish in the deep Arabian Sea. Limnol. Oceanogr. 51, 2077-2083. doi: 10.4319/lo.2006.51.5.2077

Bischoff, J. L., and Rosenbauer, R. J. (1985). An empirical equation of state for hydrothermal seawater (3.2 percent $\mathrm{NaCl}$ ). Am. J. Sci. 285, 725-763.

Blöthe, M., Wegorzewski, A., Müller, C., Simon, F., Kuhn, T., and Schippers, A. (2015). Manganese-cycling microbial communities inside deep-sea manganese nodules. Environ. Sci. Technol. 49, 7692-7700.

Boltenkov, B. (2012). Mechanisms of formation of deep-sea ferromanganese nodules: mathematical modeling and experimental results. Geochem. Int. 50, $125-132$.

Boulais, O., Woodward, B., Schlining, B., Lundsten, L., Barnard, K., Bell, K. C., et al. (2020). FathomNet: an underwater image training database for ocean exploration and discovery. arXiv [Preprint]. arXiv:2007.00114.

Bradley, J., Arndt, S., Amend, J., Burwicz, E., Dale, A. W., Egger, M., et al. (2020). Widespread energy limitation to life in global subseafloor sediments. Sci. Adv. 6:eaba0697. doi: 10.1126/sciadv.aba0697 
Brandt, A., Gooday, A. J., Brandao, S. N., Brix, S., Brökeland, W., Cedhagen, T., et al. (2007). First insights into the biodiversity and biogeography of the Southern Ocean deep sea. Nature 447, 307-311. doi: 10.1038/nature 05827

Cario, A., Oliver, G. C., and Rogers, K. L. (2019). Exploring the deep marine biosphere: challenges, innovations, and opportunities. Front. Earth Sci. 7:225. doi: 10.3389/feart.2019.00225

Charlou, J. L., Donval, J. P., Konn, C., OndréAs, H., Fouquet, Y., Jean-Baptiste, P., et al. (2010). "High production and fluxes of $\mathrm{H} 2$ and $\mathrm{CH} 4$ and evidence of abiotic hydrocarbon synthesis by serpentinization in ultramafic-hosted hydrothermal systems on the Mid-Atlantic Ridge," in Diversity of hydrothermal Systems on Slow Spreading Ocean Ridges, Geophysical Monograph Series, Vol. 188, eds P. A. Rona, C. W. Devey, J. Dyment, and B. J. Murton (Washington, DC: American Geophysical Union), 265-296.

Chatzievangelou, D., Doya, C., Thomsen, L., Purser, A., and Aguzzi, J. (2016). High-frequency patterns in the abundance of benthic species near a cold-seepAn Internet Operated Vehicle application. PLoS One 11:e0163808. doi: 10.1371/ journal.pone. 0163808

Chua, E. J., Savidge, W., Short, R. T., Cardenas-Valencia, A. M., and Fulweiler, R. W. (2016). A review of the emerging field of underwater mass spectrometry. Front. Mar. Sci. 3:209. doi: 10.3389/fmars.2016.00209

Connelly, D. P., Copley, J. T., Murton, B. J., Stansfield, K., Tyler, P. A., German, C. R., et al. (2012). Hydrothermal vent fields and chemosynthetic biota on the world's deepest seafloor spreading centre. Nat. Commun. 3:620. doi: 10.1038/ ncomms 1636

D’Hondt, S., Inagaki, F., Zarikian, C. A., Abrams, L. J., Dubois, N., Engelhardt, T., et al. (2015). Presence of oxygen and aerobic communities from sea floor to basement in deep-sea sediments. Nat. Geosci. 8, 299-304.

D’Hondt, S., Jørgensen, B. B., Miller, D. J., Batzke, A., Blake, R., Cragg, B. A., et al. (2004). Distributions of microbial activities in deep subseafloor sediments. Science 306, 2216-2221. doi: 10.1126/science.1101155

D’Hondt, S., Spivack, A. J., Pockalny, R., Ferdelman, T. G., Fischer, J. P., Kallmeyer, J., et al. (2009). Subseafloor sedimentary life in the South Pacific Gyre. Proc. Natl. Acad. Sci. U.S.A. 106, 11651-11656. doi: 10.1073/pnas.0811793106

Dachs, J., Lohmann, R., Ockenden, W. A., Méjanelle, L., Eisenreich, S. J., and Jones, K. C. (2002). Oceanic biogeochemical controls on global dynamics of persistent organic pollutants. Environ. Sci. Technol. 36, 4229-4237. doi: 10. $1021 /$ es025724k

David, O., Lannou, C., Monod, H., Papaïx, J., and Traore, D. (2017). Adaptive diversification in heterogeneous environments. Theor. Popul. Biol. 114, 1-9. doi: $10.1016 /$ j.tpb.2016.11.003

Dutt, K. (2020). Race and racism in the geosciences. Nat. Geosci. 13, 2-3. doi: 10.1038/s41561-019-0519-z

Edwards, K. J., Glazer, B., Rouxel, O. J., Bach, W., Emerson, D., Davis, R. E., et al. (2011). Ultra-diffuse hydrothermal venting supports Fe-oxidizing bacteria and massive umber deposition at $5000 \mathrm{~m}$ off Hawaii. ISME J. 5, 1748-1758. doi: 10.1038 /ismej.2011.48

Felden, J., Ruff, S. E., Ertefai, T., Inagaki, F., Hinrichs, K., and Wenzhöfer, F. (2014). Anaerobic methanotrophic community of a 5346-m-deep vesicomyid clam colony in the Japan Trench. Geobiology 12, 183-199. doi: 10.1111/gbi.12078

Flores, G. E., Campbell, J. H., Kirshtein, J. D., Meneghin, J., Podar, M., Steinberg, J. I., et al. (2011). Microbial community structure of hydrothermal deposits from geochemically different vent fields along the Mid-Atlantic Ridge. Environ. Microbiol. 13, 2158-2171. doi: 10.1111/j.1462-2920.2011.02463.x

Fortunato, C. S., Butterfield, D. A., Larson, B., Lawrence-Slavas, N., Algar, C. K., Zeigler Allen, L., et al. (2021). Seafloor incubation experiment with deep-sea hydrothermal vent fluid reveals effect of pressure and lag time on autotrophic microbial communities. Appl. Environ. Microbiol. 87:e00078-21. doi: 10.1128/ AEM.00078-21

Francheteau, J., Armijo, R., Cheminée, J., Hekinian, R., Lonsdale, P., and Blum, N. (1990). 1 Ma East Pacific Rise oceanic crust and uppermost mantle exposed by rifting in Hess Deep (equatorial Pacific Ocean). Earth Planet. Sci. Lett. 101, 281-295.

Freeman, R. B., and Huang, W. (2014). Collaboration: strength in diversity. Nat. News 513:305. doi: 10.1038/513305a

Fryer, P. (2002). Recent studies of serpentinite occurrences in the oceans: mantleocean interactions in the plate tectonic cycle. Geochemistry 62, 257-302. doi: 10.1078/0009-2819-00020
Fujikura, K., Kojima, S., Tamaki, K., Maki, Y., Hunt, J., and Okutani, T. (1999). The deepest chemosynthesis-based community yet discovered from the hadal zone, 7326 m deep, in the Japan Trench. Mar. Ecol. Prog. Ser. 190, 17-26.

Gage, J. D., and Tyler, P. A. (1991). Deep-Sea Biology: A Natural History of Organisms at the Deep-Sea Floor. New York, NY: Cambridge University Press.

Garel, M., Bonin, P., Martini, S., Guasco, S., Roumagnac, M., Bhairy, N., et al. (2019). Pressure-Retaining sampler and high-pressure systems to study deepsea microbes under in situ conditions. Front. Microbiol. 10:453. doi: 10.3389/ fmicb. 2019.00453

German, C., and Seyfried, W. Jr. (2014). "8.7-hydrothermal processes," in Treatise on Geochemistry, 2nd Edn, eds H. D. Holland and K. K. Turekian (Oxford: Elsevier), 191-233.

Goffredi, S. K., and Orphan, V. J. (2010). Bacterial community shifts in taxa and diversity in response to localized organic loading in the deep sea. Environ. Microbiol. 12, 344-363. doi: 10.1111/j.1462-2920.2009.02072.x

Hartman, S. E., Bett, B. J., Durden, J. M., Henson, S. A., Iversen, M., Jeffreys, R. M., et al. (2021). Enduring science: three decades of observing the Northeast Atlantic from the Porcupine Abyssal Plain Sustained Observatory (PAP-SO). Prog. Oceanogr. 191:102508.

Herndl, G. J., and Reinthaler, T. (2013). Microbial control of the dark end of the biological pump. Nat. Geosci. 6, 718-724. doi: 10.1038/ngeo1921

Hirano, N. (2011). Petit-spot volcanism: a new type of volcanic zone discovered near a trench. Geochem. J. 45, 157-167. doi: 10.2343/geochemj.1.0111

Hirano, N., Machida, S., Abe, N., Morishita, T., Tamura, A., and Arai, S. (2013). Petit-spot lava fields off the central Chile trench induced by plate flexure. Geochem. J. 47, 249-257.

Hirano, N., Machida, S., Sumino, H., Shimizu, K., Tamura, A., Morishita, T., et al. (2019). Petit-spot volcanoes on the oldest portion of the Pacific plate. Deep Sea Res. Part I Oceanogr. Res. Pap. 154:103142. doi: 10.1016/j.dsr.2019.103142

Hirano, N., Takahashi, E., Yamamoto, J., Abe, N., Ingle, S. P., Kaneoka, I., et al. (2006). Volcanism in response to plate flexure. Science 313, 1426-1428. doi: $10.1126 /$ science. 1128235

Inagaki, F., Nunoura, T., Nakagawa, S., Teske, A., Lever, M., Lauer, A., et al. (2006). Biogeographical distribution and diversity of microbes in methane hydratebearing deep marine sediments on the Pacific Ocean Margin. Proc. Natl. Acad. Sci. U.S.A. 103, 2815-2820. doi: 10.1073/pnas.0511033103

Jamieson, A. J., Malkocs, T., Piertney, S. B., Fujii, T., and Zhang, Z. (2017). Bioaccumulation of persistent organic pollutants in the deepest ocean fauna. Nat. Ecol. Evol. 1, 1-4. doi: 10.1038/s41559-016-0051

Jones, D. O. B., Kaiser, S., Sweetman, A. K., Smith, C. R., Menot, L., Vink, A., et al. (2017). Biological responses to disturbance from simulated deep-sea polymetallic nodule mining. PLoS One 12:e0171750. doi: 10.1371/journal.pone. 0171750

Juniper, S. K., and Sibuet, M. (1987). Cold seep benthic communities in Japan subduction zones: spatial organization, trophic strategies and evidence for temporal evolution. Mar. Ecol. Prog. Ser. 40, 115-126.

Kinsey, J. C., and German, C. R. (2013). Sustained volcanically-hosted venting at ultraslow ridges: Piccard hydrothermal field, Mid-Cayman Rise. Earth Planet. Sci. Lett. 380, 162-168. doi: 10.1016/j.epsl.2013.08.001

Klein, F., Bach, W., and McCollom, T. M. (2013). Compositional controls on hydrogen generation during serpentinization of ultramafic rocks. Lithos 178, 55-69. doi: 10.1016/j.lithos.2013.03.008

Klein, F., Marschall, H. R., Bowring, S. A., Humphris, S. E., and Horning, G. (2017). Mid-ocean ridge serpentinite in the Puerto Rico Trench: from seafloor spreading to subduction. J. Petrol. 58, 1729-1754. doi: 10.1093/petrology/ egx071

Koschinsky, A., and Hein, J. R. (2017). Marine ferromanganese encrustations: archives of changing oceans. Elements An Int. Mag. Mineral. Geochem. Petrol. 13, 177-182.

Krause, S., Molari, M., Gorb, E., Gorb, S., Kossel, E., and Haeckel, M. (2020). Persistence of plastic debris and its colonization by bacterial communities after two decades on the abyssal seafloor. Sci. Rep. 10:9484.

Langenkämper, D., Zurowietz, M., Schoening, T., and Nattkemper, T. W. (2017). Biigle 2.0-browsing and annotating large marine image collections. Front. Mar. Sci. 4:83. doi: 10.3389/fmars.2017.00083

Le, J. T., Levin, L. A., and Carson, R. T. (2017). Incorporating ecosystem services into environmental management of deep-seabed mining. Deep Sea Res. Part II Top. Stud. Oceanogr. 137, 486-503. doi: 10.1016/j.dsr2.2016.08.007 
León-Zayas, R., Novotny, M., Podell, S., Shepard, C. M., Berkenpas, E., Nikolenko, S., et al. (2015). Single cells within the Puerto Rico trench suggest hadal adaptation of microbial lineages. Appl. Environ. Microbiol. 81, 8265-8276. doi: 10.1128/AEM.01659- 15

Levin, L. A., Etter, R. J., Rex, M. A., Gooday, A. J., Smith, C. R., Pineda, J., et al. (2001). Environmental influences on regional deep-sea species diversity. Annu. Rev. Ecol. Syst. 32, 51-93.

Lusty, P. A., and Murton, B. J. (2018). Deep-ocean mineral deposits: metal resources and windows into earth processes. Elements An Int. Mag. Mineral. Geochem. Petrol. 14, 301-306.

Machida, S., Kogiso, T., and Hirano, N. (2017). Petit-spot as definitive evidence for partial melting in the asthenosphere caused by $\mathrm{CO}_{2}$. Nat. Commun. 8:14302. doi: $10.1038 /$ ncomms 14302

Martin, W., Baross, J., Kelley, D., and Russell, M. J. (2008). Hydrothermal vents and the origin of life. Nat. Rev. Microbiol. 6, 805-814.

McClain, C. R., and Barry, J. P. (2010). Habitat heterogeneity, disturbance, and productivity work in concert to regulate biodiversity in deep submarine canyons. Ecology 91, 964-976. doi: 10.1890/09-0087.1

McClain, C. R., and Lundsten, L. (2015). Assemblage structure is related to slope and depth on a deep offshore P acific seamount chain. Mar. Ecol. 36, 210-220.

McClain, C. R., Lundsten, L., Barry, J., and DeVogelaere, A. (2010). Assemblage structure, but not diversity or density, change with depth on a northeast Pacific seamount. Mar. Ecol. 31, 14-25. doi: 10.1111/j.1439-0485.2010.00367.x

McDermott, J. M., Sylva, S. P., Ono, S., German, C. R., and Seewald, J. S. (2018). Geochemistry of fluids from Earth's deepest ridge-crest hot-springs: Piccard hydrothermal field, Mid-Cayman Rise. Geochim. Cosmochim. Acta 228, 95-118. doi: 10.1016/j.gca.2018.01.021

McDermott, J. M., Sylva, S. P., Ono, S., German, C. R., and Seewald, J. S. (2020). Abiotic redox reactions in hydrothermal mixing zones: decreased energy availability for the subsurface biosphere. Proc. Natl. Acad. Sci. U.S.A. 117, 20453-20461. doi: 10.1073/pnas.2003108117

McNichol, J., Sylva, S. P., Thomas, F., Taylor, C. D., Sievert, S. M., and Seewald, J. S. (2016). Assessing microbial processes in deep-sea hydrothermal systems by incubation at in situ temperature and pressure. Deep Sea Res. Part I Oceanogr. Res. Pap. 115, 221-232. doi: 10.1016/j.dsr.2016.06.011

Meyer, J. L., Jaekel, U., Tully, B. J., Glazer, B. T., Wheat, C. G., Lin, H.-T., et al. (2016). A distinct and active bacterial community in cold oxygenated fluids circulating beneath the western flank of the Mid-Atlantic ridge. Sci. Rep. 6:22541.

Miller, K. A., Thompson, K. F., Johnston, P., and Santillo, D. (2018). An overview of seabed mining including the current state of development, environmental impacts, and knowledge gaps. Front. Mar. Sci. 4:418. doi: 10.3389/fmars.2017. 00418

Morishita, T., Hirano, N., Sumino, H., Sato, H., Shibata, T., Yoshikawa, M., et al. (2020). Alkali basalt from the Seifu Seamount in the sea of Japan: post-spreading magmatism in a back-arc setting. Solid Earth 11, 23-36. doi: 10.5194/se-11-232020

Mullineaux, L. S., Adams, D. K., Mills, S. W., and Beaulieu, S. E. (2010). Larvae from afar colonize deep-sea hydrothermal vents after a catastrophic eruption. Proc. Natl. Acad. Sci. U.S.A. 107, 7829-7834. doi: 10.1073/pnas.0913187107

Niner, H. J., Ardron, J. A., Escobar, E. G., Gianni, M., Jaeckel, A., Jones, D. O., et al. (2018). Deep-sea mining with no net loss of biodiversity - an impossible aim. Front. Mar. Sci. 5:53. doi: 10.3389/fmars.2018.00053

Nomaki, H., Ogawa, N. O., Ohkouchi, N., Suga, H., Toyofuku, T., Shimanaga, M., et al. (2008). Benthic foraminifera as trophic links between phytodetritus and benthic metazoans: carbon and nitrogen isotopic evidence. Mar. Ecol. Prog. Ser. 357, 153-164.

Ohara, Y., Reagan, M. K., Fujikura, K., Watanabe, H., Michibayashi, K., Ishii, T., et al. (2012). A serpentinite-hosted ecosystem in the Southern Mariana Forearc. Proc. Natl. Acad. Sci. U.S.A. 109, 2831-2835. doi: 10.1073/pnas.1112005109

Orcutt, B. N., Bradley, J. A., Brazelton, W. J., Estes, E. R., Goordial, J. M., Huber, J. A., et al. (2020). Impacts of deep-sea mining on microbial ecosystem services. Limnol. Oceanogr. 65, 1489-1510. doi: 10.1002/lno.11403

Page, S. (2019). The Diversity Bonus. Princeton, NJ: Princeton University Press.

Peoples, L. M., Norenberg, M., Price, D., McGoldrick, M., Novotny, M., Bochdansky, A., et al. (2019). A full-ocean-depth rated modular lander and pressure-retaining sampler capable of collecting hadal-endemic microbes under in situ conditions. Deep Sea Res. Part I Oceanogr. Res. Pap. 143, 50-57. doi: 10.1016/j.dsr.2018.11.010

Pickrell, J. (2020). Scientists push against barriers to diversity in the field sciences. Science 374:375.

Purser, A., Thomsen, L., Barnes, C., Best, M., Chapman, R., Hofbauer, M., et al. (2013). Temporal and spatial benthic data collection via an internet operated Deep Sea Crawler. Methods Oceanogr. 5, 1-18. doi: 10.1016/j.mio.2013.07.001

Reveillaud, J., Reddington, E., McDermott, J., Algar, C., Meyer, J. L., Sylva, S., et al. (2016). Subseafloor microbial communities in hydrogen-rich vent fluids from hydrothermal systems along the M id-C ayman R ise. Environ. Microbiol. 18, 1970-1987. doi: 10.1111/1462-2920.13173

Rex, M. A., and Etter, R. J. (2010). Deep-Sea Biodiversity: Pattern and Scale. Cambridge, MA: Harvard University Press.

Riehl, T., Wölfl, A.-C., Augustin, N., Devey, C. W., and Brandt, A. (2020). Discovery of widely available abyssal rock patches reveals overlooked habitat type and prompts rethinking deep-sea biodiversity. Proc. Natl. Acad. Sci. U.S.A. 117, 15450-15459. doi: 10.1073/pnas.1920706117

Røy, H., Kallmeyer, J., Adhikari, R. R., Pockalny, R., Jørgensen, B. B., and D’Hondt, S. (2012). Aerobic microbial respiration in 86-million-year-old deep-sea red clay. Science 336, 922-925. doi: 10.1126/science.1219424

Rüpke, L. H., Morgan, J. P., Hort, M., and Connolly, J. A. (2004). Serpentine and the subduction zone water cycle. Earth Planet. Sci. Lett. 223, 17-34. doi: 10.1016/j.epsl.2004.04.018

Scheuermann, P. P., Tan, C., and Seyfried, W. E. Jr. (2018). Quartz solubility in the two-phase region of the $\mathrm{NaCl}-\mathrm{H} 2_{O}$ system: an experimental study with application to the piccard hydrothermal field, mid-Cayman rise. Geochem. Geophys. Geosyst. 19, 3570-3582. doi: 10.1029/2018gc007610

Scheuermann, P. P., Xing, Y., Ding, K., and Seyfried, W. E. Jr. (2020). Experimental measurement of $\mathrm{H} 2$ (aq) solubility in hydrothermal fluids: application to the Piccard hydrothermal field, Mid-Cayman Rise. Geochim. Cosmochim. Acta 283, 22-39. doi: 10.1016/j.gca.2020.05.020

Schrenk, M. O., Brazelton, W. J., and Lang, S. Q. (2013). Serpentinization, carbon, and deep life. Rev. Mineral. Geochem. 75, 575-606.

Shank, T. M. (2010). Seamounts: deep-ocean laboratories of faunal connectivity, evolution, and endemism. Oceanography 23, 108-122. doi: 10.5670/oceanog. 2010.65

Shulse, C. N., Maillot, B., Smith, C. R., and Church, M. J. (2017). Polymetallic nodules, sediments, and deep waters in the equatorial North Pacific exhibit highly diverse and distinct bacterial, archaeal, and microeukaryotic communities. MicrobiologyOpen 6:e00428. doi: 10.1002/mbo3.428

Simon-Lledó, E., Bett, B. J., Huvenne, V. A., Schoening, T., Benoist, N. M., Jeffreys, R. M., et al. (2019). Megafaunal variation in the abyssal landscape of the Clarion Clipperton Zone. Prog. Oceanogr. 170, 119-133.

Simon-Lledó, E., Pomee, C., Ahokava, A., Drazen, J. C., Leitner, A. B., Flynn, A., et al. (2020). Multi-scale variations in invertebrate and fish megafauna in the mid-eastern Clarion Clipperton Zone. Progr. Oceanogr. 187:102405.

Sleep, N. H., Bird, D. K., and Pope, E. C. (2011). Serpentinite and the dawn of life. Philos. Trans. R. Soc. B Biol. Sci. 366, 2857-2869. doi: 10.1098/rstb.2011.0129

Smith, C. R., and Baco, A. R. (2003). Ecology of whale falls at the deep-sea floor. Oceanogr. Mar. Biol. 41, 311-354.

Smith, C. R., Glover, A. G., Treude, T., Higgs, N. D., and Amon, D. J. (2015). Whalefall ecosystems: recent insights into ecology, paleoecology, and evolution. Ann. Rev. Mar. Sci. 7, 571-596. doi: 10.1146/annurev-marine-010213-135144

Smith, K. Jr., Sherman, A., McGill, P., Henthorn, R., Ferreira, J., Connolly, T., et al. (2021). Abyssal Benthic Rover, an autonomous vehicle for long-term monitoring of deep-ocean processes. Sci. Robot. 6:eabl4925. doi: 10.1126/ scirobotics.abl 4925

Smith, K. L., Ruhl, H. A., Huffard, C. L., Messié, M., and Kahru, M. (2018). Episodic organic carbon fluxes from surface ocean to abyssal depths during long-term monitoring in NE Pacific. Proc. Natl. Acad. Sci. U.S.A. 115:12235. doi: $10.1073 /$ pnas. 1814559115

Smith, K., Huffard, C., and Ruhl, H. (2020). Thirty-year time series study at a station in the abyssal NE Pacific: an introduction. Deep Sea Res. Part II Top. Stud. Oceanogr. 173:104764. doi: 10.1016/j.dsr2.2020.104764

Snelgrove, P. V., Soetaert, K., Solan, M., Thrush, S., Wei, C.-L., Danovaro, R., et al. (2018). Global carbon cycling on a heterogeneous seafloor. Trends Ecol. Evol. 33, 96-105. doi: 10.1016/j.tree.2017.11.004 
Soltwedel, T., Bauerfeind, E., Bergmann, M., Bracher, A., Budaeva, N., Busch, K., et al. (2016). Natural variability or anthropogenically-induced variation? Insights from 15 years of multidisciplinary observations at the arctic marine LTER site HAUSGARTEN. Ecol. Indic. 65, 89-102. doi: 10.1016/j.ecolind.2015. 10.001

Spearman, J., Taylor, J., Crossouard, N., Cooper, A., Turnbull, M., Manning, A., et al. (2020). Measurement and modelling of deep sea sediment plumes and implications for deep sea mining. Sci. Rep. 10:5075. doi: 10.1038/s41598-02061837-y

Suess, E., Bohrmann, G., Von Huene, R., Linke, P., Wallmann, K., Lammers, S., et al. (1998). Fluid venting in the eastern Aleutian subduction zone. J. Geophys. Res. Solid Earth 103, 2597-2614. doi: 10.1029/97jb02131

Sweetman, A. K., Smith, C. R., Shulse, C. N., Maillot, B., Lindh, M., Church, M. J., et al. (2019). Key role of bacteria in the short-term cycling of carbon at the abyssal seafloor in a low particulate organic carbon flux region of the eastern Pacific Ocean. Limnol. Oceanogr. 64, 694-713. doi: 10.1002/lno.11069

Sylvan, J. B., Wankel, S. D., LaRowe, D. E., Charoenpong, C. N., Huber, J. A., Moyer, C. L., et al. (2017). Evidence for microbial mediation of subseafloor nitrogen redox processes at Loihi Seamount, Hawaii. Geochim. Cosmochim. Acta 198, 131-150. doi: 10.1016/j.gca.2016.10.029

Takai, K., Gamo, T., Tsunogai, U., Nakayama, N., Hirayama, H., Nealson, K. H., et al. (2004). Geochemical and microbiological evidence for a hydrogenbased, hyperthermophilic subsurface lithoautotrophic microbial ecosystem (HyperSLiME) beneath an active deep-sea hydrothermal field. Extremophiles 8, 269-282. doi: 10.1007/s00792-004-0386-3

Tamburini, C., Boutrif, M., Garel, M., Colwell, R. R., and Deming, J. W. (2013). Prokaryotic responses to hydrostatic pressure in the ocean-a review. Environ. Microbiol. 15, 1262-1274. doi: 10.1111/1462-2920.12084

Tecchio, S., Van Oevelen, D., Soetaert, K., Navarro, J., and Ramírez-Llodra, E. (2013). Trophic dynamics of deep-sea megabenthos are mediated by surface productivity. PLoS One 8:e63796. doi: 10.1371/journal.pone.0063796

Thiel, H. (2003). "Anthropogenic impacts on the deep sea," in Ecosystems of the World, ed. P. A. Tyler (Amsterdam: Elsevier), 427-472. doi: 10.1016/j. marenvres.2014.03.008

Thomsen, L., Aguzzi, J., Costa, C., De Leo, F., Ogston, A., and Purser, A. (2017). The oceanic biological pump: rapid carbon transfer to depth at continental margins during winter. Sci. Rep. 7:10763. doi: 10.1038/s41598-017-11075-6

Thurber, A. R., Sweetman, A. K., Narayanaswamy, B. E., Jones, D. O., Ingels, J., and Hansman, R. (2014). Ecosystem function and services provided by the deep sea. Biogeosciences 11, 3941-3963. doi: 10.5194/bg-11-3941-2014

Trope, Y., and Liberman, N. (2010). Construal-level theory of psychological distance. Psychol. Rev. 117:440. doi: 10.1037/a0018963

Van Cauwenberghe, L., Vanreusel, A., Mees, J., and Janssen, C. R. (2013). Microplastic pollution in deep-sea sediments. Environ. Pollut. 182, 495-499. doi: 10.1016/j.envpol.2013.08.013

van Keken, P. E., Hacker, B. R., Syracuse, E. M., and Abers, G. A. (2011). Subduction factory: 4. Depth-dependent flux of $\mathrm{H} 2 \mathrm{O}$ from subducting slabs worldwide. J. Geophys. Res. Solid Earth 116:B01401.

Vanreusel, A., Hilario, A., Ribeiro, P. A., Menot, L., and Arbizu, P. M. (2016). Threatened by mining, polymetallic nodules are required to preserve abyssal epifauna. Sci. Rep. 6:26808. doi: 10.1038/srep26808

Vinogradova, N. (1997). Zoogeography of the abyssal and hadal zones. Adv. Mar. Biol. 32, 325-387. doi: 10.1016/s0065-2881(08) 60019-x
Von Damm, K., Bischoff, J. L., and Rosenbauer, R. (1991). Quartz solubility in hydrothermal seawater; an experimental study and equation describing quartz solubility for up to $0.5 \mathrm{M} \mathrm{NaCl}$ solutions. Am. J. Sci. 291, 977-1007. doi: 10.2475/ajs.291.10.977

Vonnahme, T. R., Molari, M., Janssen, F., Wenzhöfer, F., Haeckel, M., Titschack, J., et al. (2020). Effects of a deep-sea mining experiment on seafloor microbial communities and functions after 26 years. Sci. Adv. 6:eaaz5922. doi: 10.1126/ sciadv.aaz5922

Wakeham, S. G., Lee, C., Hedges, J. I., Hernes, P. J., and Peterson, M. J. (1997). Molecular indicators of diagenetic status in marine organic matter. Geochim. Cosmochim. Acta 61, 5363-5369. doi: 10.1016/s0016-7037(97) 00312-8

Wedding, L. M., Friedlander, A., Kittinger, J., Watling, L., Gaines, S., Bennett, M., et al. (2013). From principles to practice: a spatial approach to systematic conservation planning in the deep sea. Proc. R. Soc. B Biol. Sci. 280:20131684. doi: 10.1098/rspb.2013.1684

Wessel, P., Sandwell, D. T., and Kim, S.-S. (2010). The global seamount census. Oceanography 23, 24-33. doi: 10.5670/oceanog.2010.60

Wilson, C. E. (2019). Status of the Geoscience Workforce 2018. Alexandria, VA: American Geosciences Institute.

Woodall, L. C., Talma, S., Steeds, O., Stefanoudis, P., Jeremie-Muzungaile, M.M., and de Comarmond, A. (2021). Co-development, co-production and co-dissemination of scientific research: a case study to demonstrate mutual benefits. Biol. Lett. 17:20200699. doi: 10.1098/rsbl.2020.0699

Woolley, S. N. C., Tittensor, D. P., Dunstan, P. K., Guillera-Arroita, G., LahozMonfort, J. J., Wintle, B. A., et al. (2016). Deep-sea diversity patterns are shaped by energy availability. Nature 533, 393-396. doi: 10.1038/nature1 7937

Yi, L., Medina-Elizalde, M., Kletetschka, G., Yao, H., Simon, Q., Paterson, G., et al. (2020). The potential of marine ferromanganese nodules from Eastern Pacific as recorders of Earth's magnetic field changes during the past $4.7 \mathrm{Myr}$ : a geochronological study by magnetic scanning and authigenic 10Be/9Be dating. J. Geophys. Res. Solid Earth 125:e2019JB018639.

Zeppilli, D., Pusceddu, A., Trincardi, F., and Danovaro, R. (2016). Seafloor heterogeneity influences the biodiversity-ecosystem functioning relationships in the deep sea. Sci. Rep. 6:26352. doi: 10.1038/srep26352

Conflict of Interest: The authors declare that the research was conducted in the absence of any commercial or financial relationships that could be construed as a potential conflict of interest.

Publisher's Note: All claims expressed in this article are solely those of the authors and do not necessarily represent those of their affiliated organizations, or those of the publisher, the editors and the reviewers. Any product that may be evaluated in this article, or claim that may be made by its manufacturer, is not guaranteed or endorsed by the publisher.

Copyright (c) 2022 Marlow, Anderson, Reysenbach, Seewald, Shank, Teske, Wanless and Soule. This is an open-access article distributed under the terms of the Creative Commons Attribution License (CC BY). The use, distribution or reproduction in other forums is permitted, provided the original author(s) and the copyright owner(s) are credited and that the original publication in this journal is cited, in accordance with accepted academic practice. No use, distribution or reproduction is permitted which does not comply with these terms. 